\title{
Water Footprint for Garlic under Irrigation Levels and Agrispon Application
}

\author{
Ahmed Farag ${ }^{1, a^{*}}$, Mohamed Abdrabbo ${ }^{1, b}$, Zakaria Maharik ${ }^{1, c}$ \\ and Rasha El-Morshedy ${ }^{1, d}$ \\ ${ }^{1}$ Central Laboratory for Agricultural Climate (CLAC), \\ Agricultural Research Center (ARC), Cairo, Egypt \\ aawny_a@yahoo.com, babdrabbo@yahoo.com, 'zmaharik@yahoo.com, \\ drmorshedy@hotmail.com
}

\begin{abstract}
Keywords: soil analysis, soil physical properties, fresh and dry weight, vegetative characterstics,
\end{abstract} garlic yield, blue water, water.

\begin{abstract}
Field experiment was conducted in Giza, Egypt, during two growing seasons of 2017-2018 and 2018-2019 on garlic crop, with the objective of investigating the effect ofdifferent irrigation levels $(60,80$ and $100 \%$ of water requirements and theircombination with the foliar applications of agrispon (with 0.5 and $1.0 \mathrm{ml} /$ liter)on growth and yield. The results indicated that increased irrigation levels up to $100 \%$ led to increased vegetative characterstics of garlic and that the lowest growth and productivity was obtained by $60 \%$ irrigation level. When considering spray applicationof agrispon; with $1.0 \mathrm{ml} / \mathrm{L}$ increased growth and productivity followed by $0.5 \mathrm{ml} / \mathrm{L}$; while control treatment gave the lowest productivity during the both seasons.Interaction effect between irrigation levels and agrispon treatments indicated that 100\%irrigation level combined with $1.0 \mathrm{ml} / \mathrm{L}$ foliar application of agrispon gave the highest garlic productivity followed by $100 \%$ irrigation level combined with 0.5 $\mathrm{ml} / \mathrm{L}$ foliar application. The chemical analysis showed that the highest NPK was obtained by $100 \%$ irrigation level combined with $1.0 \mathrm{ml} / \mathrm{L}$ agrispon application during the both seasons.Regarding water footprint, the highest irrigation water footprint was obtained by $80 \%$ irrigation level followed by $60 \%$ irrigation level, while the lowest footprint was obtained by $100 \%$ irrigation level due to high garlic productivity under $100 \%$ irrigation level. The estimated water footprint for garlic was $525 \mathrm{~m}^{3} /$ ton. The blue water footprint for garlic was $422 \mathrm{~m}^{3} /$ ton about $80 \%$ of total water footprint, while water percentage about $20 \%$ with value of $103 \mathrm{~m}^{3} /$ ton.
\end{abstract}

\section{Introduction}

Increasing irrigation quantity from 60 to $100 \%$ evapotranspiration increased significantly plant vegetative growth (El-Dakroury, 2008). Using drip irrigation and applying $100 \%$ of evapotranspiration enhanced plants growth parameters and yield of garlic plants (Mandefro and Quraishi, 2015). Gyanendra et al. (2016) reported that drip irrigation has significant influence on garlic productivity. Garlic vegetative growth was the highest under $75 \%$ of evapotranspiration treatment, and declined with increasing irrigation amounts up to $100 \%$ of evapotranspiration. Abd El-Hady and Eldardiry (2016) reported that drip irrigation system has a recognized impact on increasing growth characters, garlic yield, and water productivity. Abdrabbo et al., (2014) reported that increased irrigation quantity up to $100 \%$ of irrigation requirement led to improve root distribution and ability to absorb water and nutrient from soil which increased metabolism processes and then growth and productivity.

Syltine (1983) and Abdel Nabi et al., (2014) reported that spray application by agrispon produced higher fruit weights and harvested number of fruits per plant as compared with control treatment. Badr et al., (1997) found higher yield by spraying agrispon at $400 \mathrm{ml} /$ feddan compared to control treatment. Abdel Naby et al. (2012) revealed that application of agrispon two times during the season led to increase the onion bulb weight; they also mentioned that the positive impact on crop quality and quantity and reduces the use of mineral fertilizer. 
Agrispon is a plant and mineral extract containing growth promoter components, application of agrispon during the plant growth season enhance growth and productivity (Karishma et al., 2019). The use of Agrispon led to enhance plant canopy due to enhance the metabolism of plant which led to enhance the ability of use the absorbed water and nutrient and then give higher production (Anonymous, 2012). Agrispon is a natural bio-stimulant that improves plant performance and/or yield. Agrispon improve plant growth especially under soil or weather conditions stresses (Rakesh and Agarwal, 2014).

The Water Footprint (WFP) concept is an indicator to express the water use in the production chain of commodities. The Water Footprint of a commodity is realized as the total volume of freshwater that is consumed or polluted during the whole production process steps. For agricultural commodities, water consumption mainly refers to crop water consumption (green and blue water) during the growing period and water pollution (grey water) mainly relates to the leaching of fertilizers and pesticides that are applied to the field. WF divides the water use into three components, i.e., green, blue and grey water which are specified geographically and temporally (Mekonnen and Hoekstra et al., 2011a).

\section{Theory}

This study performed to investigate the effects of different irrigation level and spray application with a grispon(plant and mineral extract) and how their interaction can affect productivity of garlic plants. It was considered to estimate water foot print for garlic production.

\section{Materials and Methods}

This study was carried on two field trials during 2017/2018 and 2018/2019 seasons, at the Central Laboratory for Agricultural Climate Experimental Farm, Dokki, Giza Governorate - Egypt. The coordinate of the experimental site was $30.04588 \mathrm{~N}$ and $31.20463 \mathrm{E}$.

\section{Soil samples}

Soil samples were taken before soil preparation for cultivation. Both mechanical and chemical properties of the soil were determined as following: The mechanical analysis was determined using the international pipette method according to Gee and Bauder (1986) summarized in Table (1). Chemical analysis of the soil including $\mathrm{pH}$, nutrients and organic residues were determined as following: The $\mathrm{pH}$ value was determined by using a $\mathrm{pH}$ meter in a soil water suspension (1:2.5). In addition to electrical conductivity (EC) and soluble ions were determined in the soil according to Westerman (1990). Available P was determined according to Chapman and Pratt (1982).

Table 1. Mechanical and chemical properties of the soil before cultivation

\begin{tabular}{|c|c|c|c|c|c|c|c|c|}
\hline \multicolumn{2}{|c|}{ Soil depth/ cm } & \multicolumn{2}{|c|}{ Sand $\%$} & Clay \% & Silt \% & Texture & FC $^{*} \%$ & $\mathbf{P W P}^{* *} \%$ \\
\hline \multicolumn{2}{|l|}{$0-30$} & \multicolumn{2}{|l|}{7.7} & 50.5 & 40.8 & silty clay & 33.20 & 14.40 \\
\hline $\mathrm{ECe}$ & \multirow{3}{*}{$\mathrm{pH}$} & \multicolumn{7}{|c|}{ milliequivalent/1 } \\
\hline \multirow{2}{*}{$(\mathrm{dS} / \mathrm{m})$} & & \multicolumn{4}{|c|}{ Cations } & \multicolumn{3}{|l|}{ Anions } \\
\hline & & $\mathrm{Ca}^{++}$ & $\mathrm{Mg}^{++}$ & $\mathrm{Na}^{+}$ & $\mathrm{K}^{+}$ & $\mathrm{CO}_{3}^{--}$ & $\mathrm{HCO}_{3}^{-}$ & $\mathrm{Cl}^{-}$ \\
\hline 0.65 & 7.68 & 2.00 & 1.00 & 1.76 & 0.27 & 0.0 & 0.95 & 1.45 \\
\hline
\end{tabular}

\section{Climate conditions}

The climatic data were collected from automated weather station allocated at the experimental site and summarized in Table (2). The climatic data were collected from automated weather station installed in the same location. 
Table 2. Average monthly climatic data of Dokki location during garlic growing seasons of 2017/2018 and 2018/2019

\begin{tabular}{|c|c|c|c|c|c|}
\hline & Air temp. & RH $^{*}$ & Precipitation & W. speed $* *$ & ETo \\
\hline & ${ }^{\circ} \mathrm{C}$ & $\%$ & $\mathrm{~mm}$ & {$[\mathrm{~m} / \mathrm{s}]$} & $\mathrm{mm}$ \\
\hline Oct-17 & 23.2 & 50.04 & 0 & 0.8 & 4.5 \\
\hline Nov-17 & 20.3 & 58.39 & 0.4 & 0.6 & 3.4 \\
\hline Dec-17 & 17.7 & 62.07 & 0 & 0.6 & 2.6 \\
\hline Jan-18 & 16.1 & 57.66 & 1.5 & 0.7 & 2.2 \\
\hline Feb-18 & 17.5 & 59.34 & 4.4 & 0.4 & 2.4 \\
\hline Mar-18 & 21.2 & 47.99 & 0.8 & 0.6 & 3.2 \\
\hline Apr-18 & 22.1 & 50.41 & 0 & 1.0 & 3.5 \\
\hline May-18 & 27.7 & 45.71 & 0 & 0.8 & 4.4 \\
\hline Oct-18 & 25.0 & 55.38 & 0 & 0.6 & 4.6 \\
\hline Nov-18 & 20.2 & 64.1 & 0.6 & 0.2 & 3.5 \\
\hline Dec-18 & 15.8 & 64.39 & 4.8 & 0.3 & 2.2 \\
\hline Jan-19 & 13.6 & 50.9 & 1.4 & 0.3 & 1.9 \\
\hline Feb-19 & 15.1 & 56.83 & 0.6 & 0.3 & 2.3 \\
\hline Mar-19 & 17.6 & 55.31 & 7.5 & 0.6 & 2.9 \\
\hline Apr-19 & 21.0 & 48.39 & 0 & 0.6 & 4.4 \\
\hline May-19 & 27.3 & 38.28 & 0 & 0.6 & 4.8 \\
\hline & & & 22 & & \\
\hline
\end{tabular}

\section{Plant materials and treatments}

Garlic plants (Allium sativum L.) Sids 40 cultivar was planted on the 14 and 12 September of 2017 and 2018, respectively. The irrigation treatment started at the first of October during the both seasons. Beds with one meter width was prepared for cultivating garlic. Each bed contained two lines of polyethylene lateral $16 \mathrm{~mm}$ diameter. Four rows of garlic was cultivated in each bed. The distances emitters were $0.30 \mathrm{~m}$ apart; four plants was cultivated for each emitter in two rows. The distance between each two plants in row was $15 \mathrm{~cm}$. One meter was left between each two irrigation treatments as a border among the treatments. The experimental plot was 12 square meter (six meters length and two meters width). The total amount of applied fertilizers were $50 \mathrm{~kg} \mathrm{~N}, 30 \mathrm{~kg} \mathrm{P}{ }_{2} \mathrm{O}_{5}$ and $40 \mathrm{~kg} \mathrm{~K} \mathrm{~K}_{2} \mathrm{O}$ per Fadden.

The present experiment involved 9 treatments, which were resulted from the combinations of three irrigation levels and three spray application with tree replicates. The main plots was occupied by three irrigation levels: 60,80 and $100 \%$ of irrigation requirements (IR). Table (3) represent the irrigation water requirement for garlic during the two seasons. The tabulated data were for $100 \%$ irrigation level; irrigation water quantities for 60 and 80\%tratments were derived from 100\% irrigation level. The sub - plots were occupied with the following three foliar application treatments:

1- Foliar application with tap water (control treatment).

2- Foliar application with Agrispon at the rate of $0.5 \mathrm{ml} / 1 \mathrm{~L}$.

3- Foliar application with Agrispon at rate of $1 \mathrm{ml} / 1 \mathrm{~L}$.

The agrispon foliar application was applied two times during the growing season, first time after 60 days and second time was 90 days from garlic cultivation during the two seasons.

The irrigation levels calculations were performed, while the control irrigation was using the drip irrigation system practiced through the manual valves for each hose at the top of the drip lines in the experimental plots. The quantity of irrigation water was calculated by Food and Agricultural Organization (FAO) Penman- Monteith (PM) procedure, FAO 56 method (Allen et al., 1998).

Samples of three plants from each plot were taken randomly after 95 days after cultivation to measure the following growth parameters; plant height $(\mathrm{cm})$, No. of leaves/plant, fresh and dry weight of garlic 
leaf. At harvest time, bulb diameter $(\mathrm{cm})$, No. of cloves /bulb, bulb fresh wt. (g) and average weight of a clove $(\mathrm{g})$ were recorded from random sample of 50 plant per plot. At the harvest time, bulb diameter, number of cloves per bulb, average weight of garlic clove and bulb fresh weight were measured for different treatments. Leaf samples were taken after 140 dates from cultivation to analyze NPK percentages. For element analysis of leaves ( $\% \mathrm{~N}, \mathrm{P}$ and $\mathrm{K})$, five plant leaves samples of each plot were dried at $70{ }^{\circ} \mathrm{C}$ in an air forced oven for 48 hours. Dried leaves were digested in $\mathrm{H}_{2} \mathrm{SO}_{4} / \mathrm{H}_{2} \mathrm{O}_{2}$ mixture according to the method described by Allen (1974). Total nitrogen was determined by Kjeldahl method according to the procedure described by FAO (1980). Phosphorus content was determined using spectrophotometer according to Watanabe and Olsen (1965). Potassium content was determined photo-metrically using Flame photometer as described by Chapman and Pratt (1961).

Table 3. Irrigation quantities under different irrigation levels for garlic in dokki farm during $2017 / 2018$ and $2018 / 2019$ seasons

\begin{tabular}{|c|c|c|c|c|c|c|c|}
\hline \multirow{3}{*}{ Months } & ETo & Kc & ETc & \multirow{2}{*}{$\begin{array}{c}\text { Leaching } \\
\text { requirement }\end{array}$} & \multirow{2}{*}{\begin{tabular}{|l|} 
Irrigation \\
Efficiency
\end{tabular}} & \multirow{2}{*}{$\begin{array}{c}\text { Daily } \\
\text { irrigation }\end{array}$} & \multirow{2}{*}{$\begin{array}{c}\text { Total monthly } \\
\text { Irrigation }\end{array}$} \\
\hline & & & & & & & \\
\hline & $\mathrm{mm}$ & & $\mathrm{mm}$ & & & m3/feddan & m3/feddan \\
\hline Oct-2017 & 4.5 & 0.7 & 3.15 & 3.6 & 4.3 & 18 & 555 \\
\hline Nov-2017 & 3.4 & 0.85 & 2.89 & 3.3 & 3.9 & 16 & 493 \\
\hline Dec-2017 & 2.6 & 0.95 & 2.47 & 2.8 & 3.3 & 14 & 435 \\
\hline Jan-2018 & 2.2 & 1.1 & 2.42 & 2.8 & 3.3 & 14 & 426 \\
\hline Feb-2018 & 2.4 & 1.1 & 2.64 & 3.0 & 3.6 & 15 & 420 \\
\hline Mar-2018 & 3.2 & 0.9 & 2.88 & 3.3 & 3.9 & 16 & 507 \\
\hline Apr-2018 & 3.5 & 0.8 & 2.8 & 3.2 & 3.8 & 16 & 477 \\
\hline May-2018 & 4.4 & 0.7 & 3.08 & 3.5 & 4.2 & 18 & 175 \\
\hline \multicolumn{7}{|l|}{ total } & 3489 \\
\hline Oct-2018 & 4.6 & 0.7 & 3.2 & 3.7 & 4.4 & 18 & 567 \\
\hline Nov-2018 & 3.5 & 0.9 & 3.0 & 3.4 & 4.0 & 17 & 507 \\
\hline Dec-2018 & 2.2 & 1.0 & 2.1 & 2.4 & 2.8 & 12 & 368 \\
\hline Jan-2019 & 1.9 & 1.1 & 2.1 & 2.4 & 2.8 & 12 & 368 \\
\hline Feb-2019 & 2.3 & 1.1 & 2.5 & 2.9 & 3.4 & 14 & 403 \\
\hline Mar-2019 & 2.9 & 0.9 & 2.6 & 3.0 & 3.5 & 15 & 460 \\
\hline Apr-2019 & 4.4 & 0.8 & 3.5 & 4.0 & 4.8 & 20 & 600 \\
\hline May-2019 & 4.8 & 0.7 & 3.4 & 3.9 & 4.5 & 19 & 191 \\
\hline \multicolumn{7}{|l|}{ total } & 3460 \\
\hline
\end{tabular}

\section{Experimental design}

The treatment of every experiment was arranged in split plot design in three replicates.

\section{Green water footprint (GWF)}

The green water footprint (GWF) of a crop is calculated as the ratio of the volume of green water used for crop production, CWUg ( $\mathrm{m}^{3}$ /acre), to the weight of crop produced, Y (ton /acre).

$$
\mathrm{WF}_{\text {green }}=\mathrm{CWU}_{\mathrm{g}} / \mathrm{Y}
$$

The green water is calculated as the sum of green water use for each month, $\mathrm{ug}(\mathrm{mm} / \mathrm{month})$, over the entire crop period. Assuming that the irrigation requirements of the crop are fully met, the monthly water use is equal to the minimum between effective rainfall, Peff, and crop evapotranspiration, ETc (Chapagain and Orr, 2009).

$$
\mathrm{u}_{\mathrm{g}}=\min \left(\mathrm{P}_{\text {eff }}, \mathrm{ET}_{\mathrm{c}}\right)
$$

The effective rainfall depends only on the monthly rainfall. 


\section{Blue water footprint (BWF)}

The blue component of the water footprint (BWF, $\mathrm{m}^{3} /$ ton) was calculated as the blue component in crop water use (CWUblue, $\mathrm{m}^{3} / \mathrm{ha}$ ) divided by the garlic yield (Y, ton/ha). The blue component (WFproc, $\mathrm{m}^{3} /$ ton) are calculated as follows:

$$
\mathrm{WF}_{\text {blue }}=\mathrm{CWU}_{\text {blue }} / \mathrm{Y}\left(\mathrm{m}^{3} / \text { ton }\right)
$$

Blue water ingredients of crop water use $\left(\mathrm{CWU}, \mathrm{m}^{3} / \mathrm{ha}\right)$ were calculated by accumulation of daily evapotranspiration (ET, $\mathrm{mm} /$ day) over the growing season:

$$
\mathrm{CWU}_{\text {blue }}=10 \times \sum_{d=1}^{d=\text { harvest }} E T_{\text {blue }}\left(\frac{\text { volume }}{\text { area }}\right)
$$

ET blue: water evapotranspiration.

The factor 10 was used to convert water depths in millimeters into water volumes per land surface in $\mathrm{m}^{3} /$ ha.

The summation is done over the growing period from planting day one to the day of harvest. The blue water evapotranspiration has been estimated by using math model is based on the method described by Allen et al. (1998).

\section{Grey water footprint (GWF)}

The grey water footprint of crop production, which is an offer of the volume of freshwater pollution, is calculated by quantifying the volume of water required to assimilate the nutrients that reach ground- or surface water. Nutrients leaching from agricultural fields are a main cause of nonpoint source pollution of surface and subsurface water bodies.

According to Mekonnen and Hoekstra (2011a), the grey water footprint is calculated by quantifying the volume of water needed to assimilate the nutrients that reach ground- or surface water. Nutrients leaching from agricultural fields are a main cause of non-point source pollution of surface and subsurface water-bodies. In most studies, the grey water footprint is quantified as related to nitrogen use only. The grey component of the water footprint (GWF) is calculated by multiplying the fraction ( $\mathrm{f}$ ) of nitrogen that leaches or runs off by the nitrogen application rate $\left(\mathrm{L}_{\mathrm{N}}\right)$, and dividing this by the difference between the maximum acceptable concentration of nitrogen -nitrogen $\mathrm{NO}_{3}-\mathrm{N}$ $\left(\mathrm{C}_{\mathrm{N}, \max }\right)$ and the natural concentration of nitrogen $\left(\mathrm{C}_{\mathrm{N}, \mathrm{nat}}\right)$ in the receiving water-body and by the actual crop yield (Y). Naturally, to obtain an accurate figure for the grey water footprint of a crop, one needs to have a good estimate of the nitrogen fertilizer application rate for the specific crop, as well as the applied nitrogen fertilizer lost through leaching.

$$
G W F=\frac{f . L_{N}}{\left(c_{N, \text { max }}-c_{N, \text { nat }}\right) \cdot Y}
$$

The grey water footprint calculation are the values of $\mathrm{C}_{\mathrm{N} \text {,nat }}$ and $\mathrm{C}_{\mathrm{N} \text {,max }}$ in the receiving waterbodies. Until recently, most published articles that present calculations of the grey water footprint would consistently report the value of zero for $\mathrm{C}_{\mathrm{N} \text {,nat }}$ due to lack of data (Mekonnen, and Hoekstra,2001). For the maximum concentration, $\mathrm{C}_{\mathrm{N}, \max }$, stated that the recommended maximum value of nitrate in surface and groundwater by the World Health Organization and the European Union is $50 \mathrm{mg}$ nitrate $\left(\mathrm{NO}_{3}\right)$ per $\mathrm{L}$, and the maximum value recommended by US-EPA is $10 \mathrm{mg} / \mathrm{L}$ measured as nitrate nitrogen $\left(\mathrm{NO}_{3}-\mathrm{N}\right)$; thus, in most studies, the standard of $10 \mathrm{mg} / \mathrm{L} \mathrm{NO}_{3}-\mathrm{N}$ is used following Chapagain et al. (2006), which is a reasonable assumption.

The amount of $\mathrm{N}$ fertilizer used in Egypt depend on the seasons of cultivation there were two seasons of cultivation Autumn and spring, which suggest 200- 230 and 180-210 kg per feddan for plant and ratoon garlic crops, respectively. 


\section{Statistical analysis}

Analysis of data was done, using SAS program for statistical analysis. The differences among means for all traits were tested for significance at $5 \%$ level according to Waller and Duncan (1969).

\section{Results}

Vegetative growth. Application of different levels of irrigation using drip irrigation and application with agrispon had significant effect on plant heights of garlic plants gown in silt clay soil during the two studied seasons (Table 4). The tallest garlic plants was obtained under $100 \%$ irrigation level followed by $80 \%$ irrigation level with no significant differences between each of them. The shortest plants was obtained under $60 \%$ irrigation level treatment during the both seasons. Number of leaves per plant took the same trend during the both seasons.

The fresh and dry weight of garlic leaf were significantly affected by different irrigation levels; the highest fresh and dry weight of leaf were obtained by the highest irrigation level (100\% IR) followed by $80 \%$ irrigation level; the lowest leaf fresh and dry weight of leaf were obtained by $60 \%$ irrigation level during the both seasons.

Regarding the spray application with agrispon for garlic; the agrispon spray application with $1.0 \mathrm{ml} / \mathrm{L}$ had the highest vegetative growth characters (plant height, number of leaves per plant, fresh and dry weight of garlic leaf) during the two seasons. The agrispon spray application with $0.5 \mathrm{ml} / \mathrm{L}$ came in the second option. The lowest vegetative growth characters was obtained by control treatment.

As for the effect of interaction between irrigation level and agrispon application the highest vegetative growth characters was obtained by $100 \%$ irrigation level combined with $1.0 \mathrm{ml} / \mathrm{L}$ followed by $100 \%$ irrigation level combined with $0.5 \mathrm{ml} / \mathrm{L}$ of agrispon application. However, the lowest garlic vegetative growth characters was obtained by $60 \%$ irrigation level combined with control (without agrispon treatment). The same results was obtained by Abdrabbo et al. (2014) who concluded that increase in irrigation levels up to $100 \%$ of irrigation requirement led to increase the root distribution which led to absorb more water and nutrient elements and then enhanced the vegetative growth of crop. El-Dakroury, (2008) and Abd El-Hady \& Eldardiry (2016) concluded that increased quantity of irrigation water application by using drip irrigation enhance the vegetative characters of garlic plants. Farag et al., (2013) mentioned that proper irrigation quantity led to enhance the plant growth and avoid water stress. On the other hand, Abdel Naby et al. (2012) and Karishma et al.,(2019) revelad that application with agrispon by spray two times during the growing season led to increase the vegetative growth of garlic plant compared to control. Moreover, Rakesh and Agarwal, (2014) confirmed the role of agrispon in improvement of the plant growth and productivity due to better utilization of nutrients such as nitrogen and phosphorus. 
Table 4. The effect of irrigation levels and agrispon application on vegetative growth of garlic plant during 2017-2018 and 2018-2019 seasons

\begin{tabular}{|c|c|c|c|c|c|c|c|c|}
\hline & \multicolumn{4}{|c|}{ 2017-2018 } & \multicolumn{4}{|c|}{ 2018-2019 } \\
\hline \multirow{3}{*}{$\begin{array}{l}\text { Irrigation } \\
\text { levels (\%) }\end{array}$} & \multicolumn{8}{|c|}{ Plant height (cm) } \\
\hline & \multicolumn{8}{|c|}{ Spray agrispon } \\
\hline & Control & $0.5 \mathrm{ml} / \mathrm{L}$ & $1.0 \mathrm{ml} / \mathrm{L}$ & Mean & Control & $0.5 \mathrm{ml} / \mathrm{L}$ & $1.0 \mathrm{ml} / \mathrm{L}$ & Mean \\
\hline $60 \%$ & $69.2 \mathrm{e}$ & $69.1 \mathrm{e}$ & $76.1 \mathrm{bc}$ & $71.4 \mathrm{C}$ & $68.7 \mathrm{~d}$ & $70.3 \mathrm{~d}$ & $75.0 \mathrm{~d}$ & $71.3 \mathrm{C}$ \\
\hline $80 \%$ & $72.1 \mathrm{de}$ & $79.1 \mathrm{~b}$ & $83.5 \mathrm{a}$ & $78.3 \mathrm{AB}$ & $75.7 \mathrm{~cd}$ & $84.0 \mathrm{bc}$ & $89.7 \mathrm{ab}$ & $83.1 \mathrm{AB}$ \\
\hline $100 \%$ & $73.7 \mathrm{~cd}$ & $82.7 \mathrm{a}$ & $89.7 \mathrm{a}$ & $80.6 \mathrm{~A}$ & $75.0 \mathrm{~d}$ & $85.3 \mathrm{ab}$ & $92.0 \mathrm{a}$ & $84.1 \mathrm{~A}$ \\
\hline \multirow{2}{*}{ Mean } & $71.7 \mathrm{C}$ & $77.0 \mathrm{~B}$ & $81.6 \mathrm{~A}$ & & $73.1 \mathrm{C}$ & $79.9 \mathrm{~B}$ & $85.6 \mathrm{~A}$ & \\
\hline & \multicolumn{8}{|c|}{ No. of leaves / plant } \\
\hline \multirow{2}{*}{$\begin{array}{l}\text { Irrigation } \\
\text { levels (\%) }\end{array}$} & \multicolumn{8}{|c|}{ Application spray } \\
\hline & Control & $0.5 \mathrm{ml} / \mathrm{L}$ & $1.0 \mathrm{ml} / \mathrm{L}$ & Mean & Control & $0.5 \mathrm{ml} / \mathrm{L}$ & $1.0 \mathrm{ml} / \mathrm{L}$ & Mean \\
\hline $60 \%$ & $7.33 \mathrm{c}$ & $7.67 \mathrm{bc}$ & $9.33 \mathrm{ab}$ & $8.11 \mathrm{~B}$ & $7.33 \mathrm{~d}$ & $7.33 \mathrm{~d}$ & $9.00 \mathrm{abc}$ & $7.89 \mathrm{~B}$ \\
\hline $80 \%$ & $8.33 \mathrm{abc}$ & $8.67 \mathrm{abc}$ & $9.67 \mathrm{a}$ & $8.89 \mathrm{AB}$ & $7.67 \mathrm{~cd}$ & $8.00 \mathrm{~cd}$ & $9.67 \mathrm{ab}$ & $8.44 \mathrm{AB}$ \\
\hline $100 \%$ & $8.33 \mathrm{abc}$ & $9.00 \mathrm{abc}$ & $10.0 \mathrm{a}$ & $9.11 \mathrm{~A}$ & $8.00 \mathrm{~cd}$ & $8.67 \mathrm{bcd}$ & $10.33 \mathrm{a}$ & $9.00 \mathrm{~A}$ \\
\hline \multirow[t]{2}{*}{ Mean } & $8.00 \mathrm{~B}$ & $8.44 \mathrm{~B}$ & $9.67 \mathrm{~A}$ & & $7.67 \mathrm{~B}$ & $8.00 \mathrm{~B}$ & $9.67 \mathrm{~A}$ & \\
\hline & \multicolumn{8}{|c|}{ Leaves fresh wt. (g) } \\
\hline \multirow{2}{*}{$\begin{array}{l}\text { Irrigation } \\
\text { levels (\%) } \\
\end{array}$} & \multicolumn{8}{|c|}{ Application spray } \\
\hline & Control & $0.5 \mathrm{ml} / \mathrm{L}$ & $1.0 \mathrm{ml} / \mathrm{L}$ & Mean & Control & $0.5 \mathrm{ml} / \mathrm{L}$ & $1.0 \mathrm{ml} / \mathrm{L}$ & Mean \\
\hline $60 \%$ & $26.0 \mathrm{e}$ & $32.3 \mathrm{de}$ & $36.7 \mathrm{~cd}$ & $31.8 \mathrm{C}$ & $27.2 \mathrm{~d}$ & $36.0 \mathrm{c}$ & $39.3 \mathrm{bc}$ & $34.2 \mathrm{~B}$ \\
\hline $80 \%$ & $32.7 \mathrm{~d}$ & $34.3 \mathrm{~d}$ & $40.3 \mathrm{bc}$ & $35.7 \mathrm{~B}$ & $35.3 \mathrm{~cd}$ & $36.7 \mathrm{c}$ & $42.0 \mathrm{bc}$ & $38.0 \mathrm{~B}$ \\
\hline $100 \%$ & $45.3 \mathrm{~b}$ & $55.0 \mathrm{a}$ & $56.5 \mathrm{a}$ & $52.3 \mathrm{~A}$ & $47.0 \mathrm{~b}$ & $57.0 \mathrm{a}$ & $58.7 \mathrm{a}$ & $54.2 \mathrm{~A}$ \\
\hline \multirow[t]{2}{*}{ Mean } & $34.6 \mathrm{C}$ & $40.7 \mathrm{~B}$ & $44.5 \mathrm{~A}$ & & $36.5 \mathrm{C}$ & $43.2 \mathrm{~B}$ & $46.7 \mathrm{~A}$ & \\
\hline & \multicolumn{8}{|c|}{ Leaves dry wt. (g) } \\
\hline \multirow{2}{*}{$\begin{array}{l}\text { Irrigation } \\
\text { levels (\%) }\end{array}$} & \multicolumn{8}{|c|}{ Application spray } \\
\hline & Control & $0.5 \mathrm{ml} / \mathrm{L}$ & $1.0 \mathrm{ml} / \mathrm{L}$ & Mean & Control & $0.5 \mathrm{ml} / \mathrm{L}$ & $1.0 \mathrm{ml} / \mathrm{L}$ & Mean \\
\hline $60 \%$ & $5.30 \mathrm{~d}$ & $6.60 \mathrm{c}$ & $7.53 \mathrm{~b}$ & $6.48 \mathrm{~B}$ & 5.50 & $7.23 \mathrm{bcd}$ & $7.83 \mathrm{bc}$ & $6.86 \mathrm{~B}$ \\
\hline $80 \%$ & $5.63 \mathrm{~d}$ & $6.30 \mathrm{c}$ & $7.53 \mathrm{~b}$ & $6.49 \mathrm{~B}$ & 6.50 & $6.83 \mathrm{~cd}$ & $7.93 \mathrm{bc}$ & $7.09 \mathrm{~B}$ \\
\hline $100 \%$ & $7.90 \mathrm{~b}$ & $8.87 \mathrm{a}$ & $8.93 \mathrm{a}$ & $8.57 \mathrm{~A}$ & $8.00 \mathrm{~b}$ & $9.30 \mathrm{a}$ & $9.57 \mathrm{a}$ & $8.96 \mathrm{~A}$ \\
\hline Mean & $6.28 \mathrm{C}$ & $7.26 \mathrm{~B}$ & $8.00 \mathrm{~A}$ & & $6.67 \mathrm{C}$ & $7.79 \mathrm{~B}$ & $8.44 \mathrm{~A}$ & \\
\hline
\end{tabular}

Yield and yield component. Data in Tables (5) and (6) indicated that yield and yield component (bulb diameter, number of cloves per bulb, average weight of garlic clove and bulb fresh weight) of garlic significantly affected by different irrigation levels and agrispon spray treatments during the both seasons. Regarding the irrigation level, the bulb diameter, average weight of garlic clove and bulb fresh weight was obtained by the highest irrigation level (100\% IR); $80 \%$ irrigation level came in the second option; while the lowest yield and yield component of garlic was obtained by the lowest irrigation level during the both studied seasons. Number of cloves per bulb took another trend; $60 \%$ irrigation level gave the highest number of cloves per bulb followed by $80 \%$ irrigation level; the lowest number of cloves per bulb was obtained by $100 \%$ irrigation level. Despite the lowest irrigation level in this study (60\% IR) gave the highest number of cloves per bulb the $60 \%$ IR gave the lowest fresh weight of garlic bulbs because it had the lowest value of average fresh weight.

As for the spray application of agrispon during the growing season; data in tables (5 and 6) indicated that spray of agrispon $1.0 \mathrm{ml} / \mathrm{L}$ gave the highest bulb diameter, average weight of garlic clove and bulb fresh weight followed by $0.5 \mathrm{ml} / \mathrm{L}$; while the lowest bulb diameter, average weight of 
garlic clove and bulb fresh weight was obtained by control treatment during the two studied season. Number of cloves per bulb had another trend; the highest values was obtained by control treatment followed by $0.5 \mathrm{ml} / \mathrm{L}$ during the both seasons.

The interaction effect between irrigation level and agrispon application indicated that the highest bulb diameter, average weight of garlic clove and bulb fresh weight was obtained by $100 \%$ irrigation level combined with $1.0 \mathrm{ml} / \mathrm{L}$ of agrispon application; while the lowest bulb diameter, average weight of garlic clove and bulb fresh weight obtained by $60 \%$ irrigation level combined with control treatment. Number of cloves per bulb had another trend, the lowest values were obtained by $60 \%$ irrigation level combined with control treatment during the both seasons. The same results was obtained by Moustafa et al. (2017) who concluded that there are direct relations between yield and its components of bulb weight and size due to available moisture at the time of irrigation for garlic. The good irrigation management is considered one of the major agricultural practices affecting growth development and final bulb yield and quality of garlic. Due to its sensitivity to water deficiencies, a garlic plant requires irrigation frequency and adequate moisture to improve the yield and bulb quality (Karaye and Yakubu, 2007). Moreover, Ahmed, (2006) mentioned that garlic plants doesn't tolerate the excess water and water stress which decrease bulb yield up to $60 \%$ of irrigated water quantity. However, there are direct relations between yield and its components of bulb weight and size due to available moisture at the time of irrigation for garlic (Moustafa et al.,2017).

Concerning the effect of agrispon on yield and yield component, the same finidings were observed by Karishma et al.(2019), Abdel Naby et al. (2012) and Elegba and Rennie , (1984) who stated that agrispon is a biologically derived solution which enhance the soil fertility and plant growthIn this study, agrispon applied through foliar. It is better to discuss on foliar spray aspects. If it is applied in soil, this discussion part is relevant.; agrispon also increases plant resistance under drought and generally enhance plant growth.

Karishma et al.(2019) mentioned that using agrispon spray application twice during the growing season increased crop productivity up to $49 \%$ compared to the control treatment. The same results were obtained by Tamak (1997) who reported improvement in the yield of various crops due to application of agrispon. 
Table 5. The effect of irrigation levels and agrispon spray application on neck diameter, bulb diameter and number of cloves per garlic head during 2017-2018 and 2018-2019 seasons

\begin{tabular}{|c|c|c|c|c|c|c|c|c|}
\hline \multirow{4}{*}{$\begin{array}{l}\text { Irrigation } \\
\text { levels (\%) }\end{array}$} & \multicolumn{8}{|c|}{ Neck diameter $(\mathrm{cm})$} \\
\hline & \multicolumn{4}{|c|}{ 2017-2018 } & \multicolumn{4}{|c|}{ 2018-2019 } \\
\hline & \multicolumn{8}{|c|}{ Application spray } \\
\hline & Control & $0.5 \mathrm{ml} / \mathrm{L}$ & $1.0 \mathrm{ml} / \mathrm{L}$ & Mean & Control & $0.5 \mathrm{ml} / \mathrm{L}$ & $1.0 \mathrm{ml} / \mathrm{L}$ & Mean \\
\hline $60 \%$ & $0.97 \mathrm{~b}$ & $0.97 \mathrm{~b}$ & $1.13 \mathrm{ab}$ & $1.06 \mathrm{~B}$ & $1.07 \mathrm{~b}$ & $1.10 \mathrm{~b}$ & $1.23 \mathrm{ab}$ & $1.13 \mathrm{~B}$ \\
\hline $80 \%$ & $1.10 \mathrm{ab}$ & $1.10 \mathrm{ab}$ & $1.17 \mathrm{ab}$ & $1.12 \mathrm{~A}$ & $1.20 \mathrm{ab}$ & $1.20 \mathrm{ab}$ & $1.37 \mathrm{a}$ & $1.26 \mathrm{~A}$ \\
\hline $100 \%$ & $1.13 \mathrm{ab}$ & $1.13 \mathrm{ab}$ & $1.20 \mathrm{a}$ & $1.15 \mathrm{~A}$ & $1.27 \mathrm{ab}$ & $1.37 \mathrm{a}$ & $1.43 \mathrm{a}$ & $1.36 \mathrm{~A}$ \\
\hline \multirow[t]{4}{*}{ Mean } & $1.07 \mathrm{~B}$ & $1.07 \mathrm{~B}$ & $1.16 \mathrm{~A}$ & & $1.18 \mathrm{~B}$ & $1.22 \mathrm{~B}$ & $1.34 \mathrm{~A}$ & \\
\hline & \multicolumn{8}{|c|}{ Bulb diameter $(\mathrm{cm})$} \\
\hline & \multicolumn{8}{|c|}{ Application spray } \\
\hline & Control & $0.5 \mathrm{ml} / \mathrm{L}$ & $1.0 \mathrm{ml} / \mathrm{L}$ & Mean & Control & $0.5 \mathrm{ml} / \mathrm{L}$ & $1.0 \mathrm{ml} / \mathrm{L}$ & Mean \\
\hline $60 \%$ & $3.77 \mathrm{~d}$ & $4.40 \mathrm{~cd}$ & $4.57 \mathrm{c}$ & $4.24 \mathrm{C}$ & $3.77 \mathrm{e}$ & $4.30 \mathrm{cde}$ & $4.80 \mathrm{bcd}$ & $4.28 \mathrm{C}$ \\
\hline $80 \%$ & $3.83 \mathrm{~d}$ & $4.63 \mathrm{c}$ & $5.43 \mathrm{ab}$ & $4.63 \mathrm{~B}$ & $4.03 \mathrm{de}$ & $4.90 \mathrm{bcd}$ & $5.43 \mathrm{ab}$ & $4.78 \mathrm{~B}$ \\
\hline $100 \%$ & $4.47 \mathrm{~cd}$ & $4.87 \mathrm{bc}$ & $5.80 \mathrm{a}$ & $5.04 \mathrm{~A}$ & $4.63 \mathrm{bcde}$ & $5.03 \mathrm{abc}$ & $6.00 \mathrm{a}$ & $5.22 \mathrm{~A}$ \\
\hline \multirow[t]{4}{*}{ Mean } & $4.02 \mathrm{C}$ & $4.63 \mathrm{~B}$ & $5.26 \mathrm{~A}$ & & $4.14 \mathrm{c}$ & $4.74 \mathrm{~B}$ & $5.41 \mathrm{~A}$ & \\
\hline & \multicolumn{8}{|c|}{ No. of cloves /bulb } \\
\hline & \multicolumn{8}{|c|}{ Application spray } \\
\hline & Control & $0.5 \mathrm{ml} / \mathrm{L}$ & $1.0 \mathrm{ml} / \mathrm{L}$ & Mean & Control & $0.5 \mathrm{ml} / \mathrm{L}$ & $1.0 \mathrm{ml} / \mathrm{L}$ & Mean \\
\hline $60 \%$ & $13.7 \mathrm{a}$ & $12.3 \mathrm{ab}$ & $11.3 \mathrm{bcd}$ & $12.4 \mathrm{~A}$ & $14.0 \mathrm{a}$ & $12.7 \mathrm{ab}$ & $12.0 \mathrm{ab}$ & $12.9 \mathrm{~A}$ \\
\hline $80 \%$ & $11.7 \mathrm{bc}$ & $10.7 \mathrm{bcd}$ & $10.0 \mathrm{~d}$ & $10.8 \mathrm{~B}$ & $12.3 \mathrm{ab}$ & $11.7 \mathrm{~b}$ & $11.3 \mathrm{~b}$ & $11.8 \mathrm{~B}$ \\
\hline $100 \%$ & $10.7 \mathrm{bcd}$ & $10.7 \mathrm{bcd}$ & $10.3 \mathrm{~cd}$ & $10.6 \mathrm{~B}$ & $11.7 \mathrm{~b}$ & $11.7 \mathrm{~b}$ & $11.7 \mathrm{~b}$ & $11.7 \mathrm{~B}$ \\
\hline Mean & $12.0 \mathrm{~A}$ & $11.2 \mathrm{~B}$ & $10.6 \mathrm{C}$ & & $12.7 \mathrm{~A}$ & $12.0 \mathrm{AB}$ & $11.7 \mathrm{~B}$ & \\
\hline
\end{tabular}

Table 6. The effect of irrigation levels and agrispon spray application on garlic yield during 2017-2018 and 2018-2019 seasons

\begin{tabular}{|c|c|c|c|c|c|c|c|c|}
\hline & \multicolumn{4}{|c|}{2018} & \multicolumn{4}{|c|}{2019} \\
\hline & \multicolumn{8}{|c|}{ Bulb fresh weight. (g) } \\
\hline $\begin{array}{l}\text { Irrigation } \\
\text { levels (\%) }\end{array}$ & \multicolumn{8}{|c|}{ Application spray } \\
\hline & Control & $0.5 \mathrm{ml} / \mathrm{L}$ & $\begin{array}{l}1.0 \\
\mathrm{ml} / \mathrm{L}\end{array}$ & Mean & Control & $0.5 \mathrm{ml} / \mathrm{L}$ & $\begin{array}{l}1.0 \\
\mathrm{ml} / \mathrm{L}\end{array}$ & Mean \\
\hline $60 \%$ & $22.3 \mathrm{e}$ & $31.7 \mathrm{~d}$ & $36.5 \mathrm{~d}$ & $30.2 \mathrm{C}$ & $23.5 \mathrm{e}$ & $33.0 \mathrm{~d}$ & $37.0 \mathrm{~d}$ & $31.1 \mathrm{C}$ \\
\hline $80 \%$ & $24.0 \mathrm{e}$ & $42.8 \mathrm{c}$ & $52.8 \mathrm{~b}$ & $39.9 \mathrm{~B}$ & $24.4 \mathrm{e}$ & $45.5 \mathrm{c}$ & $55.0 \mathrm{~b}$ & $41.6 \mathrm{~B}$ \\
\hline $100 \%$ & $35.7 \mathrm{~d}$ & $53.3 \mathrm{~b}$ & $66.5 \mathrm{a}$ & $51.8 \mathrm{~A}$ & $37.7 \mathrm{~d}$ & $46.2 \mathrm{c}$ & $70.8 \mathrm{a}$ & $51.6 \mathrm{~A}$ \\
\hline \multirow[t]{2}{*}{ Mean } & $27.3 \mathrm{C}$ & $42.6 \mathrm{~B}$ & $51.9 \mathrm{~A}$ & & $28.5 \mathrm{C}$ & $41.6 \mathrm{~B}$ & $54.3 \mathrm{~A}$ & \\
\hline & \multicolumn{8}{|c|}{ Average weight of a clove $(\mathrm{g})$} \\
\hline $\begin{array}{l}\text { Irrigation } \\
\text { levels (\%) }\end{array}$ & \multicolumn{8}{|c|}{ Application spray } \\
\hline & Control & $0.5 \mathrm{ml} / \mathrm{L}$ & $\begin{array}{l}1.0 \\
\mathrm{ml} / \mathrm{L}\end{array}$ & Mean & Control & $0.5 \mathrm{ml} / \mathrm{L}$ & $\begin{array}{l}1.0 \\
\mathrm{ml} / \mathrm{L}\end{array}$ & Mean \\
\hline $60 \%$ & $1.63 \mathrm{~g}$ & 2.57 ef & $3.23 \mathrm{de}$ & $2.48 \mathrm{C}$ & $1.67 \mathrm{f}$ & $2.60 \mathrm{e}$ & $3.07 \mathrm{~d}$ & $2.44 \mathrm{C}$ \\
\hline $80 \%$ & $2.07 \mathrm{fg}$ & $4.03 \mathrm{c}$ & $5.30 \mathrm{~b}$ & $3.80 \mathrm{~B}$ & $1.97 \mathrm{f}$ & $3.90 \mathrm{c}$ & $4.83 \mathrm{~b}$ & $3.57 \mathrm{~B}$ \\
\hline $100 \%$ & $3.37 \mathrm{~cd}$ & $5.00 \mathrm{~b}$ & $6.47 \mathrm{a}$ & $4.94 \mathrm{~A}$ & $3.23 \mathrm{~d}$ & $4.00 \mathrm{c}$ & $6.07 \mathrm{a}$ & $4.43 \mathrm{~A}$ \\
\hline Mean & $2.56 \mathrm{C}$ & $3.87 \mathrm{~B}$ & $5.00 \mathrm{~A}$ & & $2.29 \mathrm{C}$ & $3.50 \mathrm{~B}$ & $4.66 \mathrm{~A}$ & \\
\hline
\end{tabular}


NPK percentages. Data in Table (7) show the NPK for different treatments during the two seasons; the highest NPK was obtained by $100 \%$ irrigation level followed by $80 \%$ irrigation level during the both seasons. The lowest NPK percentages were obtained by $60 \%$ irrigation level. Regarding the application spray with agrispon; the highest NPK percentages were obtained by $1.0 \mathrm{ml} / \mathrm{L}$ of agrispon spray application; while the control gave the lowest NPK percentages during the both seasons. The interaction effect between irrigation level and agrispon application indicated that $100 \%$ irrigation level combined with $1.0 \mathrm{ml} / \mathrm{L}$ of agrispon spray application gave the highest NPK percentages during the both season. The lowest irrigation level combined with control gave the lowest NPK percentages. These results agreed with Bagali et al., (2012) who stated that increase in the plant and bulbs physical characteristics due to the loss of water through evapotranspiration which is being replenished by this level at the moist root zone of the plants. Furthermore, keeping soil moisture in the root zone at low tension insure adequate soil water content and better nutrients availability for the plant throughout the period of crop growth (Abdrabbo et al., 2014). The proper availability of moisture in the soil created good conditions for increasing the mobility of nutrients in the soil and consequently increased the minerals uptake by the plants (Ezzo et al., 2010). Regarding the effect of agrispon, Rakesh and Agarwal (2014) stated that agrispon application enhanced fertilizer use efficiency than the control treatment. Nutrient uptake increased with agrispon two sprays compared application once or control treatments. Abdel Nabi et al (2014) mentioned that application with agrispon led to enhance the plant growth which promote nutrient uptake during the growing season which led to increase the nutrient concentration in plant tissues.

Table 7. The effect of irrigation levels and agrispon spray application on NPK of garlic leaf during 2017-2018 and 2018-2019 seasons

\begin{tabular}{|c|c|c|c|c|c|c|c|c|}
\hline & \multicolumn{4}{|c|}{2018} & \multicolumn{4}{|c|}{2019} \\
\hline & \multicolumn{8}{|c|}{$\mathrm{N} \%$} \\
\hline $\begin{array}{l}\text { Irrigation } \\
\text { levels (\%) }\end{array}$ & \multicolumn{8}{|c|}{ Application spray } \\
\hline & Control & $0.5 \mathrm{ml} / \mathrm{L}$ & $1.0 \mathrm{ml} / \mathrm{L}$ & Mean & Control & $0.5 \mathrm{ml} / \mathrm{L}$ & $1.0 \mathrm{ml} / \mathrm{L}$ & Mean \\
\hline $60 \%$ & $3.13 \mathrm{~g}$ & $3.57 \mathrm{f}$ & $3.80 \mathrm{e}$ & $3.50 \mathrm{C}$ & $3.33 \mathrm{~g}$ & $3.80 \mathrm{f}$ & $4.04 \mathrm{e}$ & $4.69 \mathrm{C}$ \\
\hline $80 \%$ & $3.45 \mathrm{f}$ & $3.90 \mathrm{de}$ & $4.15 b c$ & $3.83 \mathrm{~B}$ & $3.67 \mathrm{f}$ & $4.16 \mathrm{de}$ & $4.42 b c$ & $4.08 \mathrm{~B}$ \\
\hline $100 \%$ & $4.68 \mathrm{a}$ & $4.14 \mathrm{~cd}$ & $4.40 \mathrm{~b}$ & $4.41 \mathrm{~A}$ & $4.99 \mathrm{a}$ & $4.41 \mathrm{~cd}$ & $4.68 \mathrm{~b}$ & $4.72 \mathrm{~A}$ \\
\hline \multirow[t]{2}{*}{ Mean } & $3.75 \mathrm{C}$ & $3.87 \mathrm{~B}$ & $4.11 \mathrm{~A}$ & & $4.00 \mathrm{C}$ & $4.12 \mathrm{~B}$ & $4.38 \mathrm{~A}$ & \\
\hline & \multicolumn{8}{|l|}{$\mathrm{P} \%$} \\
\hline \multirow[t]{2}{*}{$\begin{array}{l}\text { Irrigation } \\
\text { levels (\%) }\end{array}$} & \multicolumn{8}{|c|}{ Application spray } \\
\hline & Control & $0.5 \mathrm{ml} / \mathrm{L}$ & $1.0 \mathrm{ml} / \mathrm{L}$ & Mean & Control & $0.5 \mathrm{ml} / \mathrm{L}$ & $1.0 \mathrm{ml} / \mathrm{L}$ & Mean \\
\hline $60 \%$ & $0.31 \mathrm{e}$ & $0.38 \mathrm{bcd}$ & $0.41 \mathrm{bcd}$ & $0.37 \mathrm{~B}$ & $0.31 \mathrm{~d}$ & $0.38 \mathrm{bcd}$ & $0.41 \mathrm{bc}$ & $0.37 \mathrm{~B}$ \\
\hline $80 \%$ & $0.37 \mathrm{de}$ & $0.40 \mathrm{bcd}$ & $0.44 a b c$ & $0.40 \mathrm{AB}$ & $0.37 \mathrm{~cd}$ & $0.42 \mathrm{abc}$ & $0.47 \mathrm{ab}$ & $0.42 \mathrm{~B}$ \\
\hline $100 \%$ & $0.38 \mathrm{cde}$ & $0.45 \mathrm{ab}$ & $0.50 \mathrm{a}$ & $0.44 \mathrm{~A}$ & $0.40 \mathrm{bcd}$ & $0.47 \mathrm{abc}$ & $0.52 \mathrm{a}$ & $0.46 \mathrm{~A}$ \\
\hline \multirow[t]{2}{*}{ Mean } & $0.35 \mathrm{C}$ & $0.41 \mathrm{~B}$ & $0.45 \mathrm{~A}$ & & $0.36 \mathrm{C}$ & $0.42 \mathrm{~B}$ & $0.47 \mathrm{~A}$ & \\
\hline & \multicolumn{8}{|l|}{$\mathrm{K} \%$} \\
\hline \multirow[t]{2}{*}{$\begin{array}{l}\text { Irrigation } \\
\text { levels (\%) }\end{array}$} & \multicolumn{8}{|c|}{ Application spray } \\
\hline & Control & $0.5 \mathrm{ml} / \mathrm{L}$ & $1.0 \mathrm{ml} / \mathrm{L}$ & Mean & Control & $0.5 \mathrm{ml} / \mathrm{L}$ & $1.0 \mathrm{ml} / \mathrm{L}$ & Mean \\
\hline $60 \%$ & $3.10 \mathrm{e}$ & $3.27 \mathrm{df}$ & $3.68 \mathrm{c}$ & $3.35 \mathrm{C}$ & $3.04 \mathrm{e}$ & $3.47 \mathrm{~cd}$ & $3.64 \mathrm{c}$ & $3.38 \mathrm{C}$ \\
\hline $80 \%$ & $3.35 \mathrm{~d}$ & $3.59 \mathrm{c}$ & $4.05 \mathrm{~b}$ & $3.66 \mathrm{~B}$ & $3.30 \mathrm{de}$ & $3.70 \mathrm{c}$ & $3.93 \mathrm{~b}$ & $3.64 \mathrm{~B}$ \\
\hline $100 \%$ & $3.67 \mathrm{c}$ & $3.94 \mathrm{~b}$ & $4.32 \mathrm{a}$ & $3.98 \mathrm{~A}$ & $3.57 \mathrm{~cd}$ & $3.99 \mathrm{~b}$ & $4.23 \mathrm{a}$ & $3.93 \mathrm{~A}$ \\
\hline Mean & $3.37 \mathrm{C}$ & $3.60 \mathrm{~B}$ & $4.02 \mathrm{~A}$ & & $3.31 \mathrm{C}$ & $3.72 \mathrm{~B}$ & $3.93 \mathrm{~A}$ & \\
\hline
\end{tabular}


Green water footprint. Data in Table (8) show the total rainfall for Dokki location during garlic growing seasons of 2017/2018 and 2018/2019. The average total yearly rainfall for Dokki location was $22 \mathrm{~mm}$ and this range was not effective rainfall. The garlic gown in Egypt depends on irrigation water not rainfall irrigation. In this study the green water footprint value equal nearly zero because the amount of monthly rainfall was a small value and this is not consider an effective rainfall.

Table (8) presented that the crop water use (CWU), yield and blue water footprint data shown that blue water footprint for garlic was lower at $100 \%$ irrigation level recorded $489 \mathrm{~m} 3 /$ ton and the highest garlic blue water footprint was found at $80 \%$ irrigation level recorded $534 \mathrm{~m} 3 /$ Ton.

As shown in Table (8) an important parameter in the calculation of the grey water footprint of garlic products is the fraction of nitrogen that leaches, or runs off to surface waters. The number of $10 \%$ is used throughout the literature for all countries and crops (Mekonnen and Hoekstra, 2011a). The water footprint (GWFP) for garlic 77 to $127 \mathrm{~m} 3 /$ ton. In fact, irrigation level and yield under different treatments can be affected by the grey water footprint. The highest garlic grey water footprint was found at $60 \%$ irrigation level recorded $127 \mathrm{~m} 3 /$ ton. The total water footprint for garlic under Egyptian condition ranged from 489 to 534 with average $525 \mathrm{~m} 3 /$ ton.

This result was agreement with (Mekonnen and Hoekstra, 2011b) who found the GWF for garlic was $145 \mathrm{~m} 3 /$ ton and GWF plus BWF for garlic was $390 \mathrm{~m} 3 /$ ton and the water footprint for garlic was $536 \mathrm{~m} 3 /$ ton.

Table 8. Crop water use (CWU m³/fadden), garlic yield (Ton/ fadden.), blue (BWF), gray (GWF) and water footprint (WFP)

\begin{tabular}{|c|c|c|c|c|c|c|c|}
\hline $\begin{array}{l}\text { Irrigation } \\
\text { levels }\end{array}$ & \multicolumn{3}{|c|}{ Yield (ton /fed.) } & CWU & BWF & GWF & TWF \\
\hline & $2017 / 2018$ & $2018 / 2019$ & Average & & & & \\
\hline \multirow{3}{*}{$\begin{array}{l}60 \% \\
80 \%\end{array}$} & 4.96 & 5.22 & 5.09 & 2076 & 408 & 127 & 534 \\
\hline & 6.04 & 6.37 & 6.21 & 2768 & 446 & 105 & 551 \\
\hline & 8.33 & 8.47 & 8.40 & 3460 & 412 & 77 & 489 \\
\hline $\begin{array}{l}100 \% \\
\text { average }\end{array}$ & & & & & 422 & 103 & 525 \\
\hline
\end{tabular}

$\mathrm{BWF}=$ blue water footprint $\mathrm{GWF}=$ grey water footprint $\mathrm{TWF}=$ total water footprint

\section{Conclusions}

Current study revealed that use $100 \%$ irrigation water combined with spray of agrispon twice during the growing season led to increase the productivity of garlic in clayey soil. The water footprint is a new and important tool that has been in use for only about a decade, but has already done a great deal in raising awareness about the critical importance of water use and the "hidden" water associated with production in modern society. The blue water footprint under this study for garlic grown in Egypt condition was $422 \mathrm{~m}^{3} /$ ton about $80 \%$ of total water footprint, while grey water percentage about $20 \%$ with value of $103 \mathrm{~m}^{3} /$ ton. The estimated water footprint for garlic of this study was $525 \mathrm{~m}^{3} / \mathrm{ton}$. The water footprint analysis is going to be used as a tool for water resources management; it should probably be expanded to include the localized impact on water resources, taking into account quantity and quality of local water resources . 


\section{References}

[1] Abd El-Hady, M. and I. E. Ebtisam. 2016. Maximize Crop Water Productivity of Garlic by Modified Fertilizer Management under Drip Irrigation. International J. of ChemTech Research, 5: 144- 150 .

[2] Abdel-Nabi, H. M. A. ; K. K.Dawa ; E. I. El - Gamily. and Y. F. E. Imryed. 2014. Impact of Mineral, Organic and Biofertilization on Growth, Yield and Quality of Cantaloupe J. Plant Production, Mansoura Univ., Vol. 5(11): 1777 - 1794.

[3] Abdel-Naby, H. M. E. ; K. K. Dawa ; E. E. El-Gamily and N. M. Salem.2012. Effect of mineral, organic fertilization and some foliar application treatments on growth and bulb yield of onion. J. Plant Production, Mansoura Univ., Vol. 3 (8): 2265 - 2276

[4] Ahmed, H.G. (2006). Effect of Irrigation Interval and Weeding Regimes on the Yield of Garlic (Allium sativum L.).Journal of Weed Science,19:290-298.

[5] Allen, S. E. (1974). Chemical analysis of ecological materials. Black-Well, Oxford, 565.

[6] Allen, R.G., L.S. Pereira, D. Raes, and M. Smith. (1998). Crop evapotranspiration: guidelines for computing crop water requirements. Irrigation and Drainage Paper nr 56. 300 p. Food and Agriculture Organization of the United Nations (FAO), Rome, Italy.

[7] Anonymous (2012). Agrispon biologically derived stimulant for crop and soil. Agricultural Sciences, Inc., 3227 Garden Brook, Dallas, Texas 75234 USA http://www.agsciinc.com/html/agrispon.html.

[8] Bagali, A.N.; H.B. Patil; M.B. Guled and R.V.Patil (2012). Effect of scheduling of drip irrigation on growth, yield and water use efficiency of onion (Allium cepa L.). Karnataka J. Agric. Sci.,25:116119.

[9] Chapagain, A. K.; Hoekstra, A. Y.; Savenije, H. H. G. and Gautam, R. (2006): The water footprint of cotton consumption: an assessment of the impact of worldwide consumption of cotton products on the water resources in the cotton producing countries, Ecological Economics, 60(1):186203.

[10]Chapagain, A. K.; Orr, S., (2009): An improved water footprint methodology linking global consumption to local water resources: A case of Spanish tomatoes. Journal of Environmental Management 90 (2) 12191228.

[11]Chapman H. D. and F. Pratt, 1961. Methods of Analysis for Soils, Plants and Water.Univ. of Calif., 35: $6-7$.

[12] Chapman, H. D. and P. F. Pratt, 1982. Methods of Plant Analysis, I. Methods of Anaylsis for Soil, Plant and Water. Chapman Publishers, Riverside, California, USA.

[13]El-Dakroury, M. A. 2008. Influence of different irrigation systems and irrigation treatments on productivity and fruit quality of some bean varieties M. Sc. Thesis, Fac. of Agri., Ain Shams University

[14]Elegba, M.S. and R.I. Rennie (1984). Agrispon: microbiological and elemental analysis and evaluation of its effect on the growth of wheat, barley, field beans and corn. Can. J. Soil Sci., 64: 621629.

[15]Ezzo M.I.; A.A. Glala, H.A. Habib, A.A. Helaly (2010). Response of sweet pepper grown in sandy and clay soil Lysimeters to water regimes. Amer-Euras J Agric\& Environ Sci., 8:18-26.

[16]FAO, (1980). Soil and plant analysis. Soils Bull. 38, 2-250 (FAO, Rome). 
[17]Gee G.W. and Bauder J.W. (1986) Particle-size analysis. In Methods of Soil Analysis. Part 1 Physical and Mineralogical Methods., Klute A. Ed. Chap. 15. American Society of Agronomy. Soil Sci. Soc. Am., 383-411.

[18] Gyanendra, P. M. S., M. Imtiyaz and M.D. Dennis. 2016. Garlic (Allium sativum L.) yield as influenced by different levels of irrigation water by drip irrigation system. International journal of innovation in engineering research \& management V: 03 Issue: 01:2348-4918.

[19]Karaye, A.K. and A.I.Yakubu (2007). Checklist of Weeds in Irrigated Garlic (Allium sativum L.) and Onion (Allium cepa L.) in Sokoto River Valley. Journal of Weed Science, 20 : 53-60.

[20]Karishma S. , M.S. Arya, U.R. Reshma1 , S.J. Anaswara1 and Syama S. Thampi. 2019. Impact of Plant Growth Regulators on Fruit Production. Int.J.Curr.Microbiol.App.Sci, 8(2): 800-814

[21] Mandefro, C. and S. Quraishi. 2015. Effect of deficit irrigation on yield and water productivity of garlic (Allium sativum L.) under drip irrigation and mulching at wolaitasoddo, Ethiopia. International Journal of Life Sciences, 4: 232-239.

[22] Mekonnen, M. M. and Hoekstra, A.Y., (2011b): National Water Footprint Accounts: The Green, Blue and Grey Water Footprint of Production and Consumption. Volume 2: Appendices. Delft, The Netherlands, UNESCO-IHE. Value of water, Research Report Series No. 50.

[23] Mekonnen, M.M. and Hoekstra, A.Y., (2011a). The green, blue and grey water footprint of crops and derived crop products. Hydrol. Earth Syst. Sci. 15, 1577-1600.

[24] Moustafa, M. M. I.1; M. A. Wally1; K. M. Refaie, and A. H. M. Abd ELWahed. 2017. Effect of different irrigation levels and salicylic acid applications on growth,yield and quality of garlic (Allium Sativum, L.). J. Biol. Chem. Environ. Sci.12(1): 301-323

[25]Rakesh K. and S.K. Agarwal.2014. Yield and yield attributes of wheat (Triticum aestivum L.) as influenced by agrispon and fertonic at varying level of fertility. International Journal of Agricultural Sciences, 4 (4): 166-170.

[26] Watanabe F. S. and S. R. Olsen, (1965). Test of an ascorbic acid method for determining phosphorus in water and Na HCO3 extracts from soil. Soil Sci. Soc. Amer. Proc. 29: 677-678.

[27] Waller, R. A. and Duncan D. B. 1969. A bayes rule for the symmetric multiple comparison problem, J. Am. Stat. Assoc 64, 1484-1504.

[28] Westerman, R. L. (1990). Soil testing and plant analysis. Soil Sci. Soc. Am. Madison, WI, USA.pp:126 